\title{
Minireview: The Epigenetic Modulation of KISS1 in Reproduction and Cancer
}

\author{
Maria Letizia Motti and Rosaria Meccariello *(D) \\ Dipartimento di Scienze Motorie e del Benessere, Università di Napoli Parthenope, via Medina 40, \\ 80133 Napoli, Italy \\ * Correspondence: rosaria.meccariello@uniparthenope.it; Tel./Fax: +39-081-5474668
}

Received: 31 May 2019; Accepted: 17 July 2019; Published: 22 July 2019

\begin{abstract}
Epigenetics describes how both lifestyle and environment may affect human health through the modulation of genome functions and without any change to the DNA nucleotide sequence. The discovery of several epigenetic mechanisms and the possibility to deliver epigenetic marks in cells, gametes, and biological fluids has opened up new perspectives in the prevention, diagnosis, and treatment of human diseases. In this respect, the depth of knowledge of epigenetic mechanisms is fundamental to preserving health status and to developing targeted interventions. In this minireview, we summarize the epigenetic modulation of the KISS1 gene in order to provide an example of epigenetic regulation in health and disease.
\end{abstract}

Keywords: epigenetics; cancer; reproduction; KISS1; KISS1R

\section{Introduction}

Epigenetics describes how lifestyle and environment modulate genome functions without any change in the DNA nucleotide sequence [1], thus affecting human health. The discovery of several epigenetic mechanisms (i.e., DNA methylation of $\mathrm{CpG}$ islands within gene promoters, chromatin remodeling, production of non-coding RNA) [2-6] and the possibility of delivering epigenetic marks (i.e., non-coding RNA) in biological fluids or target cells via exosomes or microvesicles has opened up new perspectives in the prevention, diagnosis, and treatment of human diseases [7-12].

Nevertheless, insights from genome-wide studies demonstrate that the epigenetic signature, such as histone modifications or non-coding RNA, can be passed on to the next generation through gametes and can affect gene expression in the offspring [13]. In mammals, such an intergenerational inheritance rarely represents a stable transgenerational epigenetic inheritance, but may affect the epigenome reprogramming in the embryo with consequences on embryogenesis and on the health status of the offspring [13].

In this respect, the deep knowledge of epigenetic mechanisms is fundamental to preserving health status and to developing targeted interventions.

The KISS1 gene was discovered in 1996 as a metastasis suppressor gene in malignant melanoma cells [14], and it was later heavily enrolled in the control of reproduction, with functions related to the sexual differentiation of the brain, the release of hypothalamic gonadotropin-releasing hormone $(\mathrm{GnRH})$, puberty onset, and the maintenance of reproduction in adults [15-18]. In humans, the KISS1 gene is located on chromosome 1 (1q32) and encodes a 145 amino acid protein that is proteolytically cleaved in shorter peptides such as kisspeptin-54 (Kp-54), also known as "metastin" for its ability to suppress metastasis, Kp-10, Kp-13, and Kp-14. All kisspeptins (Kps) share a common amidated C-terminal end and are capable of binding and activating the kisspeptin receptor (KISS1R), previously known as GPR54 and originally designed as Hot7t175 or AXOR12 [19-22]. Recently, a kisspeptin system comprising ligands and receptors was discovered in vertebrates [23]. Apart from cancer-related 
activities, it has a broader spectrum of actions with direct consequences on gamete quality and fertility rate, pregnancy, energy homeostasis, and body weight control, as recently summarized [24,25].

Due to the multiple facets of kisspeptin activity in biological systems, in this minireview we summarize the epigenetic modulation of the KISS1 gene in order to provide an example of epigenetic regulation in health and disease.

\section{The Epigenetic Modulation of KISS1 in Reproduction}

The deep involvement of the kisspeptin system in the central control of reproduction is well known [15], with upcoming data concerning additional peripheral activities [24,25]. Reproduction depends on the physiology of the hypothalamus-pituitary-gonad (HPG) axis. The main actor is the hypothalamic $\mathrm{GnRH}$, which is secreted in a pulsatile manner to target the pituitary gland, thus inducing the secretion of pituitary gonadotropins (follicle-stimulating hormone (FSH) and luteinizing hormone (LH)), the downstream production of sex steroids by gonads, and the progression of gametogenesis [26]. Environmental factors like diet and nutritional status, endocrine disrupting chemicals, stress, or intensive physical training may affect the functionality of the HPG axis with consequences on reproductive ability [15,27-31]. In this respect, several neuronal networks catch and integrate exogenous and endogenous environmental "cues", thus modulating the activity of GnRH-secreting neurons. Mechanisms depending, among others, on sex steroids or peripheral metabolic biosensors have been suggested $[15,26,30]$, and an inverse relationship between DNA methylation and the Gnrh1 gene expression during the peripubertal period has been reported [32]. However, in the brain, kisspeptin neurons upstream modulate the secretion of GnRH parallel to permissive or opposing signals mediated by neurokinin B (NKB) and dynorphin (DYN), thus composing the kisspeptin-NKB-DYN neuronal (KNDy) system [15].

In vertebrates, the distribution of kisspeptin neurons in the hypothalamus is sexually dimorphic. In fact, they are mainly located within the arcuate nucleus (ARC) in both males and females and in the rostral periventricular area of the third ventricle (RP3V) of rodents-which contains the sexually dimorphic anteroventral periventricular nucleus (AVPN) - and the anterior preoptic area (POA) of non-rodents in females [15,33]. Such a distribution causes sex-specific changes in Kiss1 expression and has functional consequences [34]. In fact, the KISS1 neuron population in the ARC is the main target of the negative sex steroid feedback, which occurs in both males and females; the KISS1 neuron population in the AVPN is the main target for estradiol-positive feedback only in females [15]. Interestingly, the expression of both Kiss1 and Kiss1r depends on estradiol [15,23] and a mutual enhancement with estradiol/estradiol receptors (ERs) has been reported [16,35], thus providing evidence that autocrine, paracrine, and endocrocrine pathways affect the endogenous microenvironment and modulate the activity of the kisspeptin system as a consequence.

Several studies, primarily in rodent or cell line models, have investigated the possible epigenetic regulation of Kiss1 gene in the brain, with a focus on DNA methylation, histone acetylation, and histone methylation [34]. Estrogen responsive element (ERE)-dependent and ERE-independent pathways are responsible for the estradiol-dependent expression of the Kiss1 gene in the AVPV and ARC, respectively [36]. Epigenetic mechanisms requiring activating histone $\mathrm{H} 3$ modification like $\mathrm{H} 3 \mathrm{~K} 9 / 14$ acethylation have been discovered [37] and excellently reviewed elsewhere [34,36].

In both animal and human models, the main consequence of kisspeptin signaling impairment is central hypogonadotropic hypogonadism. Conversely, gain-of-function mutations in KISS1 or KISS1R genes cause precocious puberty onset (see [16,38] for recent reviews). As a consequence, the kisspeptin system is currently considered the main gatekeeper of puberty onset, the critical developmental process particularly affected by lifestyle and environmental factors $[39,40]$.

The epigenetic modulation of Kiss1 or Kiss1r genes within the hypothalamus at puberty onset has been investigated in females, providing evidence that the methylation of both Kiss1 and Kiss1r genes promotes changes across puberty [41], with the development of highly significant puberty-specific differential promoter methylation patterns. An epigenetic mechanism of transcriptional repression 
involving the Polycomb $(\mathrm{PcG})$ silencing complex prevents the premature pubertal process in female rats. In fact, DNA methylation of the PcG genes Eed and $C b x 7$ precedes puberty, decreasing the expression of both genes. Therefore, the activation of the Kiss1 gene in the ARC at puberty is the consequence of EED protein loss from the Kiss1 promoter and activating histone $\mathrm{H} 3$ modifications such as H3K4 trimethylation and $\mathrm{H} 3 \mathrm{~K} 9 / 14$ acetylation [42]. Consistently, treatment with 5'-Azacytidine (Aza), a well-established DNA methyltransferase (DNMT) inhibitor, from postnatal day 22 to 28 (i.e., juvenile period) caused puberty failure in female rats [42] by means of failed eviction of the EED from the Kiss1 promoter in the hypothalamus. The epigenetic switch of the Kiss1 gene from transcriptional repression to activation finds dynamic counterparts in the repression of PcG into mixed-lineage leukemia 1 (MLL1) and 3 (MLL3) [43]. MLL1 and MLL3 are two components of the Trithorax group (TrxG) of modifiers which regulate chromatin remodeling. The first component is capable of changing the chromatin configuration at the promoters of Kiss1 and Tac3 from repressive to permissive, which encodes NKB [15]; the second component changes the functional status of a Kiss1 enhancer from poised to active [43]. However, due to the large number of actors in this physiological process, it is not excluded that the antagonistic epigenetic mechanism of Kiss1 transcriptional regulation may be common to additional puberty-activating genes like Nell2, TTF1, etc.

Since puberty onset is highly sensitive to nutritional and metabolic status, the epigenetic effect of diet was recently investigated by Vazquez et al. [44], who designated the sirtuin SIRT1 as fuel-sensing. This NAD ${ }^{+}$-dependent deacethylase was found to be highly expressed within the KISS1 neurons located in the ARC [44]. Interestingly, SIRT1 interacts with the PcG complex and potentiates the repressive activity of the PcG complex on the Kiss1 promoter by means of a repressive histone configuration on the same promoter, thus contributing to Kiss1 repression. As for the PcG complex, at puberty SIRT1 is evicted from the promoter of Kiss1, leading to the occurrence of Kiss1 transcription. Both under- and overnutrition exert negative and positive effects, respectively, on puberty by the delayed or premature removal of SIRT1 from the Kiss1 promoter. As for undernutrition, the central pharmacological activation of SIRT1 or SIRT1 overexpression delays puberty [44]. A schematic representation of the main epigenetic changes of Kiss1 in a female rat model is reported in Figure 1.

A)

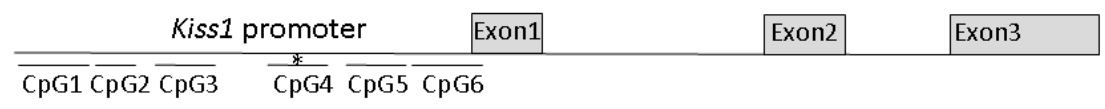

B)

Juvenile female rat

Kiss 1 transcription

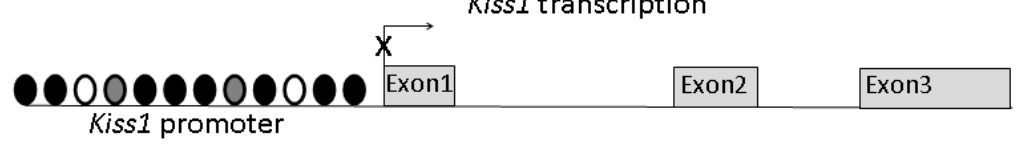

C)

Pubertal female rat

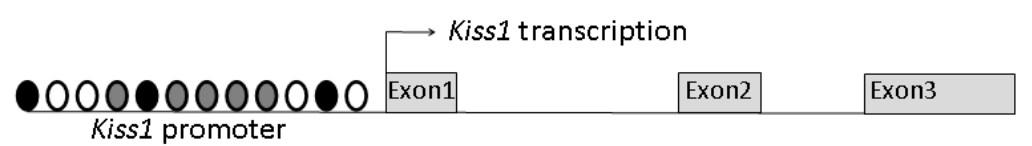

Figure 1. Schematic representation of the main epigenetic changes in the Kiss1 promoter occurring at puberty in female rats. Six CpG rich regions (CpG1-6) were predicted within the first $2 \mathrm{~kb} 5^{\prime}$ upstream at the transcription start site of Kiss1; the methylation status $\left({ }^{*}\right)$ of CpG4 changes at puberty (A). The main histone modifications of the Kiss1 promoter in juvenile (B) and pubertal (C) rats. Undernutrition and overnutrition mimic conditions in (B) and (C), leading to delayed puberty or precocious puberty, respectively. Black circles, H3K27 trimethylation; white circles, H3K9/14 acethylation; gray circles, H3K4 trimethylation. The length of the Kiss1 promoter, CpG-rich regions, exons, and introns are not represented in scale. Modified from [41] and [44]. 


\section{The Epigenetic Modulation of KISS1 in Cancer}

Cancer is a complex disease characterized by genetic and epigenetic alterations that together contribute to tumor progression. Tumor genome analysis by next-generation sequencing (NGS) highlights the presence of alterations in several epigenetic regulators, suggesting the important role of epigenetic deregulation in cancer development [45]. On these bases, several studies have shown that epigenetic alterations could represent an important target for the use of epigenetic modifiers as therapeutic candidates for some types of cancers [46-48].

In tumor development, the epigenome undergoes multiple changes that include hypermethylation in promoter $\mathrm{CpG}$ islands-in particular in tumor-suppressor genes-histone modifications that contribute to gene expression alterations, and the deregulation of miRNA expression that is associated with functional changes in target genes [49-56].

KISS1 was primarily identified as a human malignant melanoma metastasis-suppressor gene [14]. However, later, the involvement of KISS1/KISS1R in tumor development was demonstrated in several tumor types [57]. In this respect, the epigenetic regulation of KISS1 in cancer deserves particular attention, as there is a presently unfulfilled need to identify the alternative pathways required for the expression of the tumor target molecules involved in the development of metastases. In fact, epigenetic drugs have evolved in terms of specificity and efficiency for the treatment of human cancer, representing a potential possibility of successful treatment [46-48].

The kisspeptin system has multiple functions in the regulation of tumor progression [57-59]. In several cancer types the kisspeptin system has an anti-metastatic role in the regulation of cellular migration and invasion [60]. It might also be involved in other stages of tumor development [58]. For example, KISS1 is one of the candidate genes involved in the dormancy state, the phase of tumor progression in which patients appear asymptomatic and the disease remains in a state of latency for a variable period of time. In fact, cancer cells could be induced to enter a dormant state to survive within the metastatic niche, causing the metastasis to remain latent for years [61]. KISS1 expression elicits a dormancy state of the disseminated melanoma cells, inducing a suppression of metastatic colonization to multiple organs [62].

The possible epigenetic modulation of KISS1 in cancer has been investigated and, although the available data are still relatively few, research in the field is promising for cancer prevention, diagnosis, and treatment. CpG islands are present in the KISS1 promoter and in cancer the hypermethylation of the KISS1 promoter results in protein hypoexpression. In colorectal cancer (CRC), epigenetic modifications of the KISS1 promoter were shown. In particular, hypermethylation of the KISS1 promoter frequently occurred in CRC samples and rarely in normal tissues. This modification was correlated with transcription and protein expression loss. Therefore, the KISS1 methylation status was shown to have a diagnostic and prognostic utility for the clinical management of CRC patients. In fact, KISS1 methylation was related to tumor-grade metastasis, predicted recurrence, and disease-free and overall survival [63]. Therefore, KISS1 may represent a candidate target for the treatment of metastatic CRC. Furthermore, a combination of the methylation values of KISS1 and the serum concentration of carcinoembryonic antigen (CEA) have an increased prognostic value in comparison to the evaluation of CEA alone [64].

KISS1 hypermethylation has also been reported in numerous cases of bladder tumors, in correlation with increasing tumor staging and grading. An epigenetic silencing hypothesis was tested by Cebrian et al. in 2011. These authors related the expression levels of KISS1 to the histopathological stage of tumors and demonstrated by quantitative reverse transcriptase polymerase chain reaction (RT-PCR) that the methylation of the KISS1 promoter decreased KISS1 expression. The low KISS1 expression alone or in combination with the promoter methylation value was also correlated with poor disease-specific survival. Furthermore, in bladder cancer cells analyzed by methylation-specific PCR and bisulfite sequencing, KISS1 promoter hypermethylation was frequently reported and related to a low gene expression. [65]. Table 1 summarizes the different studies on tumors showing changes in KISS1 promoter methylation. 
Table 1. Changes in KISS1 promoter methylation in tumors.

\begin{tabular}{ccccc}
\hline Type of Tumor & Number of Tumors & Methylation (\%) & $\begin{array}{c}\text { CpG around the } \\
\text { Transcription Start Site }\end{array}$ & References \\
\hline Colorectal cancer (CRC) & 126 & 83.3 & - & {$[63]$} \\
CRC & 352 & 72.7 & 19 & {$[64]$} \\
Bladder cancer & 804 & 83.1 & 19 & {$[65]$} \\
\hline
\end{tabular}

At the molecular level, the epigenetic silencing of KISS1 in bladder cancer is due to the upregulation of Ubiquitin-like with PHD and RING finger domains 1 (UHRF1). The upregulation of UHRF1 enhances the methylation of CpG nucleotides and downregulates the expression of KISS1. UHRF1 was found to be overexpressed in most clinical specimens of bladder cancer in comparison to normal tissues, and in metastatic tumors in comparison to non-metastatic tumors [66].

Lastly, upcoming evidence highlights that miRNAs and long non-coding RNAs (lncRNAs) could modulate Kisspeptin-mediated signaling. Furthermore, miRNAs appear to play an important role in the regulation of proteins that modify and inhibit KISS1 expression [67]. For example, the expression of KISS1 is upregulated by the cAMP response element-binding protein (CREB). Additionally, the $\mathrm{NAD}^{+}$-dependent de-acetylase SIRT1 prevented the CREB-mediated upregulation of KISS1 in a mechanism involving miR-199b. In fact, miR-199b overexpression in CRC represses SIRT1, thus potentiating the CREB-triggered upregulation of KISS1. In this respect, miR-199b could represent a valid prognostic marker or a new possible therapeutic target for patients with CRC due to its ability to modulate the SIRT1/CREB/KISS1 pathway [68]. However, the exact mechanisms of KISS1 regulation mediated by non-coding RNAs have not yet been sufficiently outlined, and remain an interesting starting point for future studies.

In any case, the role of KISS1 in cancer is relevant. However, it is very controversial as a negative or a positive modulator, depending on the cancer context [57]. In several types of tumors, KISS1 acts as a tumor suppressor gene. Consistently, in pancreatic and ovarian cancer, KISS1/KISS1R was found to be upregulated in initial phases of cancer development, thus acting as a tumor suppressor. These patients presented a better prognosis and a longer survival rate than those with tumors in which KISS1 was downregulated by some mechanisms, like promoter hypermethylation (i.e., colorectal and bladder tumors) [57]. Conversely, in triple negative breast cancer (TNBC) cells, which lack estrogen receptor (ER) $\alpha$, progesterone receptor, and human epidermal growth factor receptor, KISS1 acts as a tumor promoter, whereas in ER $\alpha$-positive breast tumors, the situation appears more complex [57]. Hence, recent studies have just pointed out the importance of microenvironment. In fact, it has been demonstrated that KISS1 and KISS1R expression in tumor cells is not sufficient, per se, to predict cancer development behavior [57]. Thus, in the tumor microenvironment, we should evaluate not only the expression of KISS1/KISS1R in surrounding cells, but also in additional regulation systems such as in the production of cytokines $[69,70]$.

\section{Conclusions}

When observed congruently, both environmental and lifestyle factors induce the epigenetic modulation of the kisspeptin system in physiological and pathological conditions. Thus, the kisspeptin system may represent a possible epigenetic target for the treatment of human diseases and the development of personalized epigenetic therapies in reproduction and cancer.

Author Contributions: Conceptualization, M.L.M. and R.M.; Writing-Original Draft preparation, M.L.M. and R.M.; Supervision, R.M.

Funding: This research received no external funding.

Conflicts of Interest: The authors declare no conflict of interest. 


\section{References}

1. Waddington, C.H. Canalization of development and the inheritance of acquired characters. Nature 1942, 150, 563-565. [CrossRef]

2. Kim, J.K.; Samaranayake, M.; Pradhan, S. Epigenetic mechanisms in mammals. Cell. Mol. Life Sci. 2009, 66, 596-612. [CrossRef] [PubMed]

3. Ferguson-Smith, A.C. Genomic imprinting: The emergence of an epigenetic paradigm. Nat. Rev. Genet. 2011, 12, 565-575. [CrossRef] [PubMed]

4. Bannister, A.J.; Kouzarides, T. Regulation of chromatin by histone modifications. Cell Res. 2011, 21, $381-395$. [CrossRef] [PubMed]

5. Palazzo, A.F.; Eliza, S.; Lee, E.S. Non-coding RNA: What is functional and what is junk? Front. Genet. 2015, 6, 2. [CrossRef] [PubMed]

6. Taft, R.J.; Pang, K.; Mercer, T.R.; Dinger, M.; Mattick, J.S. Non-coding RNAs: Regulators of disease. J. Pathol. 2010, 220, 126-139. [CrossRef] [PubMed]

7. Brookes, E.; Shi, Y. Diverse Epigenetic Mechanisms of Human Disease. Annu. Rev. Genet. 2014, 48, $237-268$. [CrossRef]

8. Bakhshandeh, B.; Kamaleddin, M.A.; Aalishah, K.A. Comprehensive review on exosomes and microvesicles as epigenetic factors. Curr. Stem Cell Res. Ther. 2017, 12, 31-36. [CrossRef]

9. Qian, Z.; Shen, Q.; Yang, X.; Qiu, Y.; Zhang, W. The role of extracellular vesicles: An epigenetic view of the cancer microenvironment. BioMed Res. Int. 2015, 2015, 649161. [CrossRef]

10. Motti, M.L.; D'Angelo, S.; Meccariello, R. MicroRNAs, cancer and diet: Facts and new exciting perspectives. Curr. Mol. Pharmacol. 2018, 11, 90-96. [CrossRef]

11. Gelato, K.A.; Shaikhibrahim, Z.; Ocker, M.; Haendler, B. Targeting epigenetic regulators for cancer therapy: Modulation of bromodomain proteins, methyltransferases, demethylases, and microRNAs. Expert Opin. Ther. Targets 2016, 20, 783-799. [CrossRef]

12. Nervi, C.; De Marinis, E.; Codacci-Pisanelli, G. Epigenetic treatment of solid tumours: A review of clinical trials. Clin. Epigenetics 2015, 7, 127. [CrossRef]

13. Skvortsova, K.; Iovino, N.; Bogdanović, O. Functions and mechanisms of epigenetic inheritance in animals. Nat. Rev. Mol. Cell Biol. 2018, 19, 774-790. [CrossRef]

14. Lee, J.H.; Miele, M.E.; Hicks, D.J.; Phillips, K.K.; Trent, J.M.; Weissman, B.E.; Welch, D.R. KiSS-1, a novel human malignant melanoma metastasis-suppressor gene. J. Natl. Cancer Inst. 1996, 88, 1731-1737. [CrossRef] [PubMed]

15. Pinilla, L.; Aguilar, E.; Dieguez, C.; Millar, R.P.; Tena-Sempere, M. Kisspeptins and reproduction: Physiological roles and regulatory mechanisms. Physiol. Rev. 2012, 92, 1235-1316. [CrossRef]

16. Chianese, R.; Cobellis, G.; Chioccarelli, T.; Ciaramella, V.; Migliaccio, M.; Fasano, S.; Pierantoni, R.; Meccariello, R. Kisspeptins, estrogens and male fertility. Curr. Med. Chem. 2016, 23, 4070-4091. [CrossRef] [PubMed]

17. Meccariello, R.; Chianese, R.; Chioccarelli, T.; Ciaramella, V.; Fasano, S.; Pierantoni, R.; Cobellis, G. Intratesticular signals regulate germ cell progression and production of qualitatively mature spermatozoa in vertebrates. Front. Endocrinol. 2014, 5, 69. [CrossRef] [PubMed]

18. Wahab, F.; Atika, B.; Shahab, M.; Behr, R. Kisspeptin signalling in the physiology and pathophysiology of the urogenital system. Nat. Rev. Urol. 2016, 13, 21-32. [CrossRef] [PubMed]

19. Kotani, M.; Detheux, M.; Vandenbogaerde, A.; Communi, D.; Vanderwinden, J.M.; Le Poul, E.; Bre'zillon, S.; Tyldesley, R.; Suarez-Huerta, N.; Vandeput, F.; et al. The metastasis suppressor gene KiSS-1 encodes kisspeptins, the natural ligands of the orphan $G$ protein-coupled receptor GPR54. J. Biol. Chem. 2001, 276, 34631-34636. [CrossRef] [PubMed]

20. Muir, A.I.; Chamberlain, L.; Elshourbagy, N.A.; Michalovich, D.; Moore, D.J.; Calamari, A.; Szekeres, P.G.; Sarau, H.M.; Chambers, J.K.; Murdock, P.; et al. AXOR12, a novel human G protein-coupled receptor, activated by the peptide KiSS-1. J. Biol. Chem. 2001, 276, 28969-28975. [CrossRef]

21. Ohtaki, T.; Shintani, Y.; Honda, S.; Matsumoto, H.; Hori, A.; Kanehashi, K.; Terao, Y.; Kumano, S.; Takatsu, Y.; Masuda, Y.; et al. Metastasis suppressor gene KiSS-1 encodes peptide ligand of a G-protein-coupled receptor. Nature 2001, 411, 613-617. [CrossRef] [PubMed] 
22. Clements, M.K.; McDonald, T.P.; Wang, R.; Xie, G.; O’Dowd, B.F.; George, S.R.; Austin, C.P.; Liu, Q. FMRFamide-related neuropeptides are agonists of the orphan G-protein-coupled receptor GPR54. Biochem. Biophys. Res. Commun. 2001, 284, 1189-1193. [CrossRef] [PubMed]

23. Oakley, A.E.; Clifton, D.K.; Steiner, R.A. Kisspeptin signaling in the brain. Endocr. Rev. 2009, 30, 713-743. [CrossRef] [PubMed]

24. Chianese, R.; Colledge, W.H.; Fasano, S.; Meccariello, R. (Eds.) The Multiple Facets of Kisspeptin Activity in Biological Systems; Frontiers in Endocrinology; Frontiers Media: Lausanne, Switzerland, 2019. [CrossRef]

25. Chianese, R.; Colledge, W.H.; Fasano, S.; Meccariello, R. Editorial: The Multiple Facets of Kisspeptin Activity in Biological Systems. Front. Endocrinol. (Lausanne) 2018, 9, 727. [CrossRef] [PubMed]

26. Pierantoni, R.; Cobellis, G.; Meccariello, R.; Fasano, S. Evolutionary aspects of cellular communication in the vertebrate hypothalamo-hypophysio-gonadal axis. Int. Rev. Cytol. 2002, 218, 69-141. [PubMed]

27. Handa, R.J.; Weiser, M.J. Gonadal steroid hormones and the hypothalamo-pituitary-adrenal axis. Front. Neuroendocrinol. 2014, 35, 197-220. [CrossRef]

28. Arena, B.; Maffulli, N.; Maffulli, F.; Morleo, M.A. Reproductive hormones and menstrual changes with exercise in female athletes. Sports Med. 1995, 19, 278-287. [CrossRef]

29. Chianese, R.; Troisi, J.; Richards, S.; Scafuro, M.; Fasano, S.; Guida, M.; Pierantoni, R.; Meccariello, R. Bisphenol A in Reproduction: Epigenetic Effects. Curr. Med. Chem. 2018, 25, 748-770. [CrossRef]

30. Chianese, R.; Coccurello, R.; Viggiano, A.; Scafuro, M.; Fiore, M.; Coppola, G.; Operto, F.F.; Fasano, S.; Laye, S.; Pierantoni, R.; et al. Impact of Dietary Fats on Brain Functions. Curr. Neuropharmacol. 2018, 16, 1059-1085. [CrossRef]

31. Santoro, A.; Chianese, R.; Troisi, J.; Richards, S.; Nori, S.L.; Fasano, S.; Guida, M.; Plunck, E.; Viggiano, A.; Pierantoni, R.; et al. Neuro-toxic and reproductive effects of BPA. Curr. Neuropharmacol. 2019. accepted for publication on 19 July 2019.

32. Kurian, J.R.; Keen, K.L.; Terasawa, E. Epigenetic changes coincide with in vitro primate GnRH neuronal maturation. Endocrinology 2010, 151, 5359-5368. [CrossRef] [PubMed]

33. Lehman, M.N.; Hileman, S.M.; Goodman, R.L. Neuroanatomy of the kisspeptin signaling system in mammals: Comparative and developmental aspects. Adv. Exp. Med. Biol. 2013, 784, 27-62. [PubMed]

34. Semaan, S.J.; Kauffman, A.S. Emerging concepts on the epigenetic and transcriptional regulation of the Kiss1 gene. Int. J. Dev. Neurosci. 2013, 31, 452-462. [CrossRef] [PubMed]

35. Terasaka, T.; Otsuka, F.; Tsukamoto, N.; Nakamura, E.; Inagaki, K.; Toma, K.; Ogura-Ochi, K.; Glidewell-Kenney, C.; Lawson, M.A.; Makino, H. Mutual interaction of kisspeptin, estrogen and bone morphogenetic protein-4 activity in GnRH regulation by GT1-7 cells. Mol. Cell. Endocrinol. 2013, 381, 8-15. [CrossRef] [PubMed]

36. Uenoyama, Y.; Tomikawa, J.; Inoue, N.; Goto, T.; Minabe, S.; Ieda, N.; Nakamura, S.; Watanabe, Y.; Ikegami, K.; Matsuda, F.; et al. Molecular and Epigenetic Mechanism Regulating Hypothalamic Kiss1 Gene Expression in Mammals. Neuroendocrinology 2016, 103, 640-649. [CrossRef] [PubMed]

37. Tomikawa, J.; Uenoyama, Y.; Ozawa, M.; Fukanuma, T.; Takase, K.; Goto, T.; Abe, H.; Ieda, N.; Minabe, S.; Deura, C.; et al. Epigenetic regulation of Kiss1 gene expression mediating estrogen-positive feedback action in the mouse brain. Proc. Natl. Acad. Sci. USA 2012, 109, E1294-E1301. [CrossRef] [PubMed]

38. Clarke, H.; Dhillo, W.S.; Jayasena, C.N. Comprehensive Review on Kisspeptin and Its Role in Reproductive Disorders. Endocrinol. Metab. 2015, 30, 124-141. [CrossRef] [PubMed]

39. Tena-Sempere, M. Deciphering puberty: Novel partners, novel mechanisms. Eur. J. Endocrinol. 2012, 167, 733-747. [CrossRef] [PubMed]

40. Avendaño, M.S.; Vazquez, M.J.; Tena-Sempere, M. Disentangling puberty: Novel neuroendocrine pathways and mechanisms for the control of mammalian puberty. Hum. Reprod. Update 2017, 23, 737-763. [CrossRef]

41. Wyatt, A.K.; Zavodna, M.; Viljoen, J.L.; Stanton, J.A.; Gemmell, N.J.; Jasoni, C.L. Changes in methylation patterns of kiss1 and kiss1r gene promoters across puberty. Genet. Epigenetics 2013, 5, 51-62. [CrossRef] [PubMed]

42. Lomniczi, A.; Loche, A.; Castellano, J.M.; Ronnekleiv, O.K.; Bosch, M.; Kaidar, G.; Knoll, J.G.; Wright, H.; Pfeifer, G.P.; Ojeda, S.R. Epigenetic control of female puberty. Nat. Neurosci. 2013, 16, 281-289. [CrossRef] [PubMed] 
43. Toro, C.A.; Wright, H.; Aylwin, C.F.; Ojeda, S.R.; Lomniczi, A. Trithorax dependent changes in chromatin landscape at enhancer and promoter regions drive female puberty. Nat. Commun. 2018, 9, 57. [CrossRef] [PubMed]

44. Vazquez, M.J.; Toro, C.A.; Castellano, J.M.; Ruiz-Pino, F.; Roa, J.; Beiroa, D.; Heras, V.; Velasco, I.; Dieguez, C.; Pinilla, L.; et al. SIRT1 mediates obesity- and nutrient-dependent perturbation of pubertal timing by epigenetically controlling Kiss1 expression. Nat. Commun. 2018, 9, 4194. [CrossRef] [PubMed]

45. Jones, P.A.; Issa, J.P.; Baylin, S. Targeting the cancer epigenome for therapy. Nat. Rev. Genet. 2016, 17, 630-641. [CrossRef] [PubMed]

46. Mack, S.C.; Witt, H.; Piro, R.M.; Gu, L.; Zuyderduyn, S.; Stütz, A.M.; Wang, X.; Gallo, M.; Garzia, L.; Zayne, K.; et al. Epigenomic alterations define lethal CIMP-positive ependymomas of infancy. Nature 2014, 506, 445-450. [CrossRef] [PubMed]

47. Rahimi, N.; Zhang, Y.; Mina, A.; Altman, J.K.; Sukhanova, M.; Frankfurt, O.; Jennings, L.; Lu, X.; Behdad, A.; Chen, Q.; et al. An integrative approach reveals genetic complexity and epigenetic perturbation in acute Promyelocytic leukemia: A single institution experience. J. Hum. Pathol. 2019. [CrossRef]

48. Vidoni, C.; Ferraresi, A.; Secomandi, E.; Vallino, L.; Dhanasekaran, D.N.; Isidoro, C. Epigenetic targeting of autophagy for cancer prevention and treatment by natural compounds. Semin. Cancer Biol. 2019. [CrossRef] [PubMed]

49. Kanwal, R.; Gupta, S. Epigenetic modifications in cancer. Clin. Genet. 2012, 81, 303-311. [CrossRef]

50. Fraga, M.F.; Ballestar, E.; Villar-Garea, A.; Boix-Chornet, M.; Espada, J.; Schotta, G.; Bonaldi, T.; Haydon, C.; Ropero, S.; Petrie, K.; et al. Loss of acetylation at Lys16 and trimethylation at Lys20 of histone H4 is a common hallmark of human cancer. Nat. Genet. 2005, 37, 391-400. [CrossRef]

51. Hosseini, A.; Minucci, S. Alterations of histone modifications in cancer. In Epigenetics in Human Disease, 2nd ed.; Tollefsbol, T.O., Ed.; Translational Epigenetics Series; Academic Press Elsevier: London, UK, 2018; Volume 6, pp. 141-217.

52. Esteller, M. Non-coding RNAs in human disease. Nat. Rev. Genet. 2011, 12, 861-874. [CrossRef]

53. Liz, J.; Esteller, M. lncRNAs and microRNAs with a role in cancer development. Biochim. Biophys. Acta 2015, 1859, 169-176. [CrossRef] [PubMed]

54. Leenen, F.A.; Muller, C.P.; Turner, J.D. DNA methylation: Conducting the orchestra from exposure to phenotype? Clin. Epigenetics 2016, 8, 92. [CrossRef] [PubMed]

55. Sharma, S.; Kelly, T.K.; Jones, P.A. Epigenetics in cancer. Carcinogenesis 2010, 31, 27-36. [CrossRef] [PubMed]

56. Flavahan, W.A.; Gaskell, E.; Bernstein, B.E. Epigenetic plasticity and the hallmarks of cancer. Science 2017, 357, eaal2380. [CrossRef] [PubMed]

57. Guzman, S.; Brackstone, M.; Radovick, S.; Babwah, A.V.; Bhattacharya, M.M. KISS1/KISS1R in Cancer: Friend or Foe? Front. Endocrinol. (Lausanne) 2018, 9, 437. [CrossRef] [PubMed]

58. Fratangelo, F.; Carriero, M.V.; Motti, M.L. Controversial Role of Kisspeptins/KiSS-1R Signaling System in Tumor Development. Front. Endocrinol. (Lausanne) 2018, 9, 192. [CrossRef] [PubMed]

59. Ciaramella, V.; Della Corte, C.M.; Ciardiello, F.; Morgillo, F. Kisspeptin and Cancer: Molecular Interaction, Biological Functions, and Future Perspectives. Front. Endocrinol. (Lausanne) 2018, 9, 115. [CrossRef] [PubMed]

60. Corno, C.; Perego, P. KiSS1 in regulation of metastasis and response to antitumor drugs. Drug Resist. Updates 2019, 42, 12-21. [CrossRef] [PubMed]

61. Ingangi, V.; Minopoli, M.; Ragone, C.; Motti, M.L.; Carriero, M.V. Role of Microenvironment on the Fate of Disseminating Cancer Stem Cells. Front. Oncol. 2019, 9, 82. [CrossRef] [PubMed]

62. Beck, B.H.; Welch, D.R. The KiSS1 metastasis suppressor: A good night kiss for disseminated cancer cells. Eur. J. Cancer 2010, 46, 1283-1289. [CrossRef] [PubMed]

63. Chen, S.Q.; Chen, Z.H.; Lin, S.Y.; Dai, Q.B.; Fu, L.X.; Chen, R.Q. KISS1 methylation and expression as predictors of disease progression in colorectal cancer patients. World J. Gastroenterol. 2014, 20, 10071-10081. [CrossRef] [PubMed]

64. Moya, P.; Esteban, S.; Fernandez-Suarez, A.; Maestro, M.; Morente, M.; Sánchez-Carbayo, M. KiSS-1 methylation and protein expression patterns contribute to diagnostic and prognostic assessments in tissue specimens for colorectal cancer. Tumour Biol. 2013, 34, 471-479. [CrossRef] [PubMed] 
65. Cebrian, V.; Fierro, M.; Orenes-Piñero, E.; Grau, L.; Moya, P.; Ecke, T.; Alvarez, M.; Gil, M.; Algaba, F.; Bellmunt, J.; et al. KISS1 methylation and expression as tumor stratification biomarkers and clinical outcome prognosticators for bladder cancer patients. Am. J. Pathol. 2011, 179, 540-546. [CrossRef] [PubMed]

66. Zhang, Y.; Huang, Z.; Zhu, Z.; Zheng, X.; Liu, J.; Han, Z.; Ma, X.; Zhang, Y. Upregulated UHRF1 Promotes Bladder Cancer Cell Invasion by Epigenetic Silencing of KiSS1. PLoS ONE 2014, 9, e104252. [CrossRef] [PubMed]

67. Farooqi, A.A.; Attar, R.; Bageshlooyafshar, B.; Sabitaliyevich, U.Y.; Nurmurzayevich, S.B.; Yelekenova, A.B.; Gormus, U. Regulation of Kisspeptin mediated signaling by non-coding RNAs in different cancers: The beginning of a new era. Cell. Mol. Biol. (Noisy-le-grand) 2019, 65, 72-75. [CrossRef]

68. Shen, Z.L.; Wang, B.; Jiang, K.W.; Ye, C.X.; Cheng, C.; Yan, Y.C.; Zhang, J.Z.; Yang, Y.; Gao, Z.D.; Ye, Y.J.; et al. Downregulation of miR-199b is associated with distant metastasis in colorectal cancer via activation of SIRT1 and inhibition of CREB/KISS1 signaling. Oncotarget 2016, 7, 35092-35105. [CrossRef] [PubMed]

69. Dotterweich, J.; Tower, R.J.; Brandl, A.; Müller, M.; Hofbauer, L.C.; Beilhack, A.; Ebert, R.; Glüer, C.C.; Tiwari, S.; Schütze, N.; et al. The KISS1 Receptor as an In Vivo Microenvironment Imaging Biomarker of Multiple Myeloma Bone Disease. PLoS ONE 2016, 11, e0155087. [CrossRef] [PubMed]

70. Airoldi, I.; Cocco, C.; Sorrentino, C.; Angelucci, D.; Di Meo, S.; Manzoli, L.; Esposito, S.; Ribatti, D.; Bertolotto, M.; Iezzi, L.; et al. Interleukin-30 Promotes Breast Cancer Growth and Progression. Cancer Res. 2016, 76, 6218-6229. [CrossRef] [PubMed]

(C) 2019 by the authors. Licensee MDPI, Basel, Switzerland. This article is an open access article distributed under the terms and conditions of the Creative Commons Attribution (CC BY) license (http://creativecommons.org/licenses/by/4.0/). 